\title{
Hyperhomocysteinemia, ischemic stroke, and B-vitamin treatment: the jury is still out
}

\author{
J. M. K. Murthy \\ Department of Neurology, The Institute of Neurological Sciences, CARE Hospital, Hyderabad, India
}

Ischemic stroke has a high prevalence and high burden of illness. Prevention remains the optimal strategy to reduce the burden of ischemic stroke at the population level. Established causal risk factors are estimated to account for one-half of vascular disease risk. ${ }^{[1]}$ In recent years, attention has been focused on the identification and validation of novel biochemical factors that increase risk for stroke. ${ }^{[2]}$ Homocysteine (Hcy) is one such novel candidate risk factor. ${ }^{[3]}$

The available data are conflicting concerning the association between hyper-Hcy and ischemic stroke. Numerous casecontrol studies have shown an association between hyper-Hcy and stroke, but the evidence from prospective studies is not unequivocal. ${ }^{[3-7]}$ In this issue of the journal, Modi et al. ${ }^{[8]}$ in a case-control study have also shown hyper-Hcy as an important independent risk factor for ischemic stroke.

A common polymorphism $(677 \mathrm{C} \rightarrow \mathrm{T})$ in the gene encoding the N5, N10-methylenetetrahydrofolate reductase (MTHFR) enzyme, which converts dietary folate to its active cofactor in Hcy catabolism, has been studied as a candidate genetic risk factor for stroke. ${ }^{[9]}$ Data is conflicting concerning ischemic stroke risk associated with MTHFR 677T allele. Results of meta-analysis suggest an association between mild-to-moderate hyper-Hcy and ischemic stroke. The MTHFR TT genotype may have a small influence in determining susceptibility to ischemic stroke. ${ }^{[10]}$ A graded increase in ischemic stroke risk with increasing MTHFR $677 \mathrm{~T}$ allele dose was observed suggesting an influence of this polymorphism as a genetic stroke risk factor and supporting other evidence indicating a causal relationship between elevated Hcy and stoke. ${ }^{[1]}$ As T allele dose increases, this functional polymorphism causes a graded elevation in total Hcy in mild-moderate range, most pronounced in individuals with low-dietary folate consumption, which will have a greater impact in India with its vegetarian population. A hospital-based study in Western India suggests a high prevalence of both folate and vitamin $\mathrm{B}_{12}$ deficiency. ${ }^{[12]}$ In a case-control study in South India, MTHFR $\mathrm{C} 677 \mathrm{~T}$ gene mutation was found to be strongly associated with arterial stroke. ${ }^{[13]}$ In this study, tHcy levels were very high and the percentages of mutated alleles in patients with tHcy $16-50 \mu \mathrm{mol} / \mathrm{l}$ was $25.4 \%$ and in patients with tHcy $>50 \mu \mathrm{mol} / \mathrm{l}$ it was $38 \%$. Mutated alleles were not detected in any patient with $\mathrm{tHcy}<15 \mu \mathrm{mol} / \mathrm{l}$.

The mechanisms proposed to link Hcy to vascular damage, stroke, and cardiovascular disease include impairment of endothelial functions, endothelial desquamation, oxidation of lowdensity lipids, increased monocyte adhesion to the vessel wall, impaired vascular response to nitric oxide, and thrombotic tendency mediated by activation of coagulation factors and platelet dysfunction. ${ }^{[14]}$

Hcy is a sulfur-containing amino acid formed in vivo from methionine derived from dietary protein. The term Hcy describes the total circulating pool of free and protein-bound Hcy-derived moieties (Hcy, homocystine, and Hcy-cysteine mixed disulfides) that exists in equilibrium in vivo. ${ }^{[15]}$ Although the definition of hyper-Hcy has not been standardized across epidemiological studies, fasting plasma levels of Hcy between 5 and $15 \mathrm{mmol} / \mathrm{l}$ are generally considered normal. ${ }^{[4,16,17]}$ As metabolism of Hcy occurs through one of two vitamin-dependent pathways, low levels of dietary folate, vitamins $\mathrm{B}_{12}$ and $\mathrm{B}_{6}$ are associated with elevated plasma Hcy. Other factors that may be associated with elevations in Hcy include age (older than age 70), renal insufficiency, more than four cups of coffee per day, and drugs such as methotrexate, 6-azauridine, nicotinic acid, and bile acid sequestrants. ${ }^{[18]}$ Alcohol, smoking, and physical inactivity also may alter Hcy levels. ${ }^{[3]}$ Folic acid, together with vitamins $B_{12}$ and $B_{6}$ has been shown to be effective in reducing elevated plasma Hcy levels. ${ }^{[19]}$ Vitamins in stroke prevention (VISP) ${ }^{[20]}$ trial compared high-dose vitamins (folic acid $2.5 \mathrm{mg}$, vitamin $\mathrm{B}_{12} 0.4 \mathrm{mg}$, and vitamin $\mathrm{B}_{6}$ $25 \mathrm{mg}$ ) with low-dose vitamins (folic acid $0.02 \mathrm{mg}$, vitamin $\mathrm{B}_{12} 0.006 \mathrm{mg}$, and vitamin $\mathrm{B}_{6} 0.2 \mathrm{mg}$ ). Both the groups received the same daily dose of nine other vitamins according to the recommendation of the food and drug administration. An absolute difference in mean tHcy of $2 \mathrm{mmol} / \mathrm{l}$ was achieved: 
$13 \mathrm{mmol} / \mathrm{l}$ in the low-dose group vs $11 \mathrm{mmol} / \mathrm{l}$ in the highdose group. After 2 years of follow up the cumulative incidence of recurrent cerebral infarction was $8.4 \%$ in high-dose vitamins group vs $8.1 \%$ in low-dose vitamins group (RR 1.0; $95 \%$ CI $08-1.3 ; P=0.80)$. The cumulative incidence of death was $5.4 \%$ in high-dose vitamins group vs $6.3 \%$ in the lowdose group (RR 0.9; 95\% CI 0.7-1.1). However, VISP trial did not reliably exclude a modest but important reduction in the relative risk of stroke of $<20 \%$ and perhaps an even greater reduction with greater reduction in tHcy. The lower than anticipated rates of recurrent strokes in both treatment groups and the short duration of follow up also limited the statistical power of the VISP trial to reliably identify or exclude a modest but important benefit of B-vitamin therapy. ${ }^{[21]}$ The VITAmins TO Prevent Stroke (VITATOPS ${ }^{[22]}$ trial is underway.

At present, there is insufficient data to recommend routine screening and treatment of high-tHcy with B-vitamins to prevent atherosclerotic vascular disease. ${ }^{[21]}$ However, in India with high proportion of vegetarian population, no population-wide folic acid grain fortification program, and high prevalence of both folate and vitamin $\mathrm{B}_{12}$ deficiency, screening may be recommended in a select group of patients with cerebral ischemia with no identifiable risk factor for. A recent study in North India shows that $46.9 \%$ of the normal subjects studied had subnormal levels of vitamin $\mathrm{B}_{12}$ or folate. Cobalamine dificiency was five times more than folate defieciency. ${ }^{[23]}$ Levels of methylmalonic acid and Hcy are better indicators of true tissue difficiency of these two vitamins than serum levels alone. ${ }^{[24]}$ Thus it will be appropriate to correlate levles of methylmalonic acid and Hcy with vitamin $\mathrm{B}_{12}$ and folate levels.

\section{References}

1. Hassan A, Markus HS. Geneties and ischemic stroke. Brain 2000;123:1784812 .

2. Goldstein L, Adams R, Becker K, Furberg CD, Gorelick PB, Hademenos G, et al. Primary prevention of ischemic stroke: a statement for healtheare professionals from the Stroke Council of the American Heart Association. Stroke 2001;32:280-99

3. Sacco RL, Roberts JK, Jacobs BS. Homocysteine as a risk factor for ischemic stroke:an epidemiological story in evoluation. Neuroepidemiology $1998 ; 17: 167-73$.
4. Eikelboom JW, Lonn E, Genest J Jr, Hankey G, Yusuf S. Homocrsteine and cardiovascular disease: a critcal review of the epidemiologic evidence. Ann Intern Med 1999;131:363-75.

5. Bostom AG, Rosenberg IH, Silbershatz H, Jacques PF, Selhub J, D'Agostino $\mathrm{RB}$, et al. Nonfasting plasma total homocysteine levels and stroke incidence in elderly persons: the Framingham Study. Ann Intern Med 1999;131:352-5.

6. Perry IJ. Homocysteine, hypertension and strke. J Hym Hypertens 1999;13:289-93

7. Christen WG, Ajani UA, Glynn RJ, Hennekens CH. Blood levels of homocysteine and increased risks of cardiovascular disease causal or casual? Arch Intern Med 2000;160:422-34

8. Modi M, Prabhakar S, Majumdar S, Khullar M, Das P. Hyperhomocysteinemia as a risk factor for ischemic stroke:an India scenario. Neurol India $2005 ; 53: 271-2$

9. Frosst P, Blom H.J, Milos R, Govette P, Sheppard CA, Matthews RG, et al. A candidate genetic risk factor for vascular disease: a common mutation in methylenetetrahydrofolate reductase. Nat Genet 1995;10:111-3.

10. Kelly P.J, Rosand .J, Kistler .JP, Shih VE, Silveira S, Plomaritoglou A, et al Homocysteine, MTHFR $677 \mathrm{C}->\mathrm{T}$ polymorphism, and risk of ischemic stroke: Results of a meta-analysis. Neurol 2002;59:529-36.

11. Cronin S, Furie KL, Kelly P.J. Dose-related association of MTHFR 677T allele with risk of ischemic stroke: Evidence from a cumulative meta-analysis. Stroke 2005;36:1581-7.

12. Wadia RS, Bandishti S, Karche M. B12 and folate deficiency: incidence and clinical features. Neurol India 2000;48:302-4

13. Alluri RV, Mohan V, Komandur S, Chawda K, Chaudhary JR, Hasan Q. MRHFR C677T gene mutation as a risk factor for arterial stroke: a hospital-based study. Euro J Neurol 2005;11:1-5

14. Nappo F, De Rosa N, Marfella R, De Lucia D, Inorosso D, Perna AF, et al. Impairment of endothelial functions by acute hyperhomocysteinemia and reversal by antioxidant vitamins. JAMA 1999;281:2113-8.

15. Mudd SH, Finkelstein .JD, Refsum H, Ueland PM, Malinow MR, Lentz SR, et al. Homocysteine and its disulfide derivatives: a suggested consensus terminology. Arterioscler Thromb Vase Biol 2000;20:1704-6.

16. Frantzen F, Faaren AL, Alfheim I, Nordhei AK. Encyme conversion immunoassay for determining total homocysteine in plasma or serum. Clin Chem $1998 ; 44: 311-6$

17. Malinow MR, Bostom AG, Krauss RM. Homocysteine, diet, and cardiovascular diseases: a statement for healtheare professionals from the Nutrition Committee. America Heart Association. Circuation 1999;99:178-82.

18. Diaz-Arrastia R. Homocysteine and neurologic disease. Arch Neurol 2000;57:1422-8.

19. Homocysteine Lowering Trialists' Collaboration. Lowering blood homocysteine with folic acid based supplements: meta-analysis of randomized trials. BMJ $1998 ; 316 ; 894-8$

20. Toole .JF, Malinow MR, Chambless LE, Spence JD, Pettigrew LC, Howard V.J, et al. Lowering homocysteine in patients with ischemic stroke to prevent recurrent stroke, myocardial infaretion, and death: the Vitamin Intervention for Stroke Prevention (VISP) randomized controlled trial. JAMA 2004;291:565-75.

21. Hankey GJ. Secondary prevention of recurrent stroke. Stroke 2005;36:21821.

22. The VITATOPS Trial Study Group. The VITATOPS (Vitamins to Prevent Stroke) Trial:Rationale and design of an international, large, simple, randomized trial of homocysteine-lowering multivitamin therapy in patients with recent transient ischemic attack and stroke. Cerebrovase Dis 2002;13:120-6.

23. Khanduri U, Sharma A, Joshi A. Oceult cobalamin and folate deficiency in Indians. Natl Med J India 2005;18:182-3.

24. Allen RH, Stabler SP, Savage DG, Lindenbaum J. Diagnosis of cobalamin deficiency 1: Usefulness of serum methylmalonic acid and total homocysteine concentrations. Am J Hematol 1990;34:90-8. 